\title{
A Novel Single-Chain Antibody Fragment for Detection of Mannose 6-Phosphate-Containing Proteins
}

\section{Application in Mucolipidosis Type II Patients and Mice}

\author{
Sven Müller-Loennies, ${ }^{*}$ Giovanna Galliciotti, ${ }^{\dagger}$ \\ Katrin Kollmann, ${ }^{\dagger}$ Markus Glatzel, ${ }^{\ddagger}$ \\ and Thomas Braulke ${ }^{\dagger}$ \\ From the Research Center Borstel, ${ }^{*}$ Leibniz-Center for Medicine \\ and Biosciences, Borstel; and the Department of Biochemistry, \\ Children's Hospital, ${ }^{\dagger}$ and the Institute of Neuropathology, ${ }^{\ddagger}$ \\ University Medical Center Hamburg-Eppendorf, Hamburg, \\ Germany
}

Newly synthesized soluble lysosomal hydrolases require mannose 6-phosphate (Man6P) residues on their oligosaccharides for their transport to lysosomes. The formation of Man6P residues is catalyzed by the GlcNAc1-phosphotransferase, which is defective in the lysosomal storage disorders mucolipidosis type II (ML II) and ML III. Both hypersecretion and reduced intracellular level of lysosomal enzymes as well as direct sequencing of GlcNAc-1-phosphotransferase genes are important diagnostic markers for ML II and ML III. A high-affinity Man6 $P$-specific single-chain antibody fragment was generated, allowing the rapid indirect demonstration of defective GlcNAc-1-phosphotransferase. In media and extracts of cultured fibroblasts of healthy controls but not of ML II and ML III patients, several Man6P-containing proteins could be detected by anti-Man6P Western blotting. Immunoprecipitation of Man6P-containing proteins from conditioned media or mouse brain extracts followed by arylsulfatase $A$ and cathepsin D western blotting confirmed the specificity of the antibody fragment for lysosomal proteins. Application of the antibody fragment in immunohistochemistry of human brain slices from nonaffected patients showed strong neuronal immunoreactivity, which was not observed in cortical sections of an ML II patient. Finally, in brain extracts of a novel GlcNAc-1-phosphotransferase knock-in mouse no Man6P-containing proteins were detectable. Thus, the single-chain antibody fragment against Man6P was demonstrated to allow the specific, rapid, and convenient detection of $M a n 6 P$-containing proteins and facilitates the diagnosis of ML II and ML III. (Am J Pathol 2010, 177:240-247; DOI: 10.2353/ajpath.2010.090954)

Newly synthesized lysosomal enzymes are specifically modified with mannose 6-phosphate (Man6P) residues by the sequential action of two enzymes localized in the Golgi apparatus. In the first step a GlcNAc-1-phosphotransferase catalyzes the transfer GlcNAc-1-phosphate from UDP-GIcNAc on high mannose-type oligosaccharides of Iysosomal hydrolases. ${ }^{1,2}$ In the second step, GlcNAc is removed by a phosphodiester $\alpha$ - $N$-acetylglucosaminidase (uncovering enzyme) exposing the Man6P monoester on lysosomal proteins and allows the binding to two Man6P-specific receptors (MPR46 and MPR300). The MPRs mediate the transport of Man6P-containing lysosomal hydrolases from late Golgi compartments to endosomes where the MPR-ligand complexes dissociate due to low pH. ${ }^{3}$ About $5 \%$ to $20 \%$ of newly synthesized lysosomal proteins escape binding to MPR in the Golgi and become secreted. These Man6P-containing enzymes can be partially reinternalized by MPR300 localized at the cell surface and transported along the endocytic pathway to lysosomes.

Supported by Deutsche Forschungsgemeinschaft grants SFB470/C1 (S.M.-L.) and C6 (K.K. and T.B.) and Forschergruppe 885 (G.G., M.G., and T.B.).

Accepted for publication March 9, 2010.

S.M.-L. and T.B. have applied for a patent on ScFv M6P-1. None of the other authors declared any relevant financial relationships.

Supplemental material for this article can be found on http://ajp. amjpathol.org

Address reprint requests to Dr. Thomas Braulke, University Medical Center Hamburg-Eppendorf, Department of Biochemistry, Children's Hospital, Martinistr. 52, Bld N27, 20246 Hamburg, Germany. E-mail: braulke@uke.uni-hamburg.de. 
The GlcNAc-1-phosphotransferase represents a hexamer complex of two $\alpha, \beta$, and $\gamma$ subunits encoded by two genes, GNPTAB and GNPTG, respectively. ${ }^{4-6}$ Mutations in these genes were found in individuals with rare autosomal recessive mucolipidosis type II (ML II) and ML III associated with complete or partial loss of GlcNAc-1phosphotransferase activity, respectively. ${ }^{2,7-9}$ Clinically patients with ML II (also called l-cell disease) show severe skeletal abnormalities, dwarfism, cardiomegaly, and progressive psychomotor retardation leading to death in the first decade of life. ${ }^{2} \mathrm{ML} \mathrm{III} \mathrm{is} \mathrm{an} \mathrm{attenuated} \mathrm{more}$ slowly progressive form of the disease with later onset of symptoms such as skeletal dysplasia in hands, hips, and shoulders allowing the survival into adulthood..$^{10,11}$ Biochemically both disorders are characterized by missorting of multiple lysosomal enzymes due to the lack or reduced amounts of the Man6P recognition marker. The subsequent hypersecretion of lysosomal enzymes associated with their intracellular deficiency causes the accumulation of nondegraded material in lysosomes. ${ }^{12}$ Both increases in lysosomal enzyme activities in the plasma and reduced lysosomal enzyme level in patient fibroblasts are important diagnostic markers for ML II and ML III. ${ }^{2}$ Because the direct measurement of the GIcNAc1-phosphotransferase activity in fibroblasts requires the synthesis and purification of metabolically labeled [32P]UDP-GlcNAc, this method is inconvenient and not routinely used for diagnosis. Despite the major progress made during the last decade allowing the identification of the molecular defects in ML II and ML III by direct sequencing of GNPTAB and GNPTG, ${ }^{5,9,13-16}$ these methods are laborious and expensive, and intronic mutations are not definitely detectable. Therefore, a rapid, convenient, and sensitive method is required to facilitate and help the diagnosis of ML II and ML III.

Here we report on the generation of a recombinant single-chain antibody fragment against Man6P suitable as an additional tool for laboratory diagnosis of $\mathrm{ML} I \mathrm{I}$ and ML III diseases and to detect GlcNAc-1-phosphotransferase deficiency in a novel GlcNAc-1-phosphotransferase knock-in mouse model by Western blotting and immunohistochemistry.

\section{Materials and Methods}

\section{Materials}

Pentamannose 6-phosphate conjugated to bovine serum albumin (PMP-BSA) was prepared from the phosphomannan fraction of Hansenula holstii (kindly provided by M. Slodki, United States Department of Agriculture, Northern Regional Research Center, Peoria, IL) as described previously. ${ }^{17}$ As determined by anthrone reaction, the ratio of coupled ligand per mole of BSA was 20:1. Human arylsulfatase A (hASA) purified from media overexpressing mouse embryonic fibroblasts lacking Man6P-specific receptors ${ }^{18}$ was kindly provided by $T$. Dierks (University of Bielefeld, Germany). hASA was iodinated with IODO-GEN (Pierce, Rockford, IL) according to the manufacturer's instructions, yielding [ $\left.{ }^{125} \mid\right]$ ASA with a specific activity of $2 \mu \mathrm{Ci} / \mu \mathrm{g}$.

\section{Immunization and Phage Display}

Ten days after immunization and boosting of a rabbit with $0.15 \mathrm{mg}$ PMP-BSA, RNA was isolated from bone marrow cells isolated from femur. All procedures conformed to the institutional guidelines in animal facilities of the University Medical Center Hamburg-Eppendorf. The bone marrow cells were lysed for isolation of RNA using the PeqGold Trifast kit (PeqLab GmbH, Erlangen, Germany) according to the supplier's instructions. Generation and display of single-chain Fragment variable (scFv) antibody fragments on M13 phage as plll fusion protein was achieved following the protocol including primers as published ${ }^{19}$ and using the phagemid vector pComb3XSS (kindly provided by C.F. Barbas III, Scripps Research Institute, La Jolla, CA). The initial library contained $5 \times$ $10^{6}$ members, and colony PCR indicated that 19 of 20 colonies contained an antibody gene of the expected size. Phage-displayed scFv were enriched by five rounds of phage panning on PMP-BSA, which was immobilized at $1 \mu \mathrm{mol} / \mathrm{cup}$ in sodium carbonate buffer $\mathrm{pH}$ 9.2. As input for the panning procedure $\approx 10^{11}$ phages were added, and after 2 hours incubation at $37^{\circ} \mathrm{C}$ the supernatant was removed, unbound phage washed away, (first round $5 \times$; second round $10 \times$, third and fourth round $12 \times$, and fifth round $15 \times$ ), and bound phage eluted with $0.1 \mathrm{~mol} / \mathrm{L}$ glycine $/ \mathrm{HCl}$ buffer $\mathrm{pH} 2.2$ containing $0.1 \% \mathrm{BSA}$. Titration of the output after the fifth round of panning revealed $1.8 \times 10^{6} / \mathrm{ml}$ phages, which were amplified and subsequently used in enzyme-linked immunosorbent assay (ELISA; see below). The reactivity of the enriched polyclonal phage was first tested in an ELISA checkerboard titration against different concentrations of PMPBSA (3-100 pmol/cup calculated for PMP concentration). At $50 \mathrm{pmol} / \mathrm{cup}$ reactivity of the polyclonal phage was observed selectively for PMP-BSA but not for BSA. BstO I (Promega GmbH, Mannheim, Germany) restriction digest of 20 colony PCR products indicated the presence of seven different clones $(4 \times$ type $A, 10 \times B, 2 \times C$, and $1 \times D-G)$. Twelve colonies representing the different types of sequences $(5 \times B, 2 \times A, 1 \times$ each of $C-G)$ were selected for phage production, and 1:3 ( $\mathrm{v} / \mathrm{v})$ dilutions of phage were tested in ELISA against PMP-BSA. Both phages containing scFv of sequence type A (scFv M6P-1) but none of the other reacted.

\section{Expression and Purification of Soluble scFv}

For expression of soluble scFv M6P-1 its DNA was amplified by PCR $\left(3\right.$ minutes, $94^{\circ} \mathrm{C} ; 30 \times 30 \mathrm{~s}, 94^{\circ} \mathrm{C}, 60^{\circ} \mathrm{C}, 30 \mathrm{~s}$, $72^{\circ} \mathrm{C}, 1$ minute; $72^{\circ} \mathrm{C}, 10$ minutes) using the primers $5^{\prime}$ GGGGGGAATTCATGAAAAAGACAGCTATCGCGATTGC-3' (EcoRI site underlined, reverse primer, $\left.5^{\prime}\right)$ and 5'-GGGGGATCCCTTCAAATCTTCCTCACTGATTAGCTTCTGTTCAGATCTTGAGGAGACGGTGACCAGGGT-3' (BamHI site underlined, forward primer, $\left.3^{\prime}\right)$ introducing a C-terminal c-myc tag into the protein and cloned into the 
expression vector pSJF8. ${ }^{20}$ After transformation of $E$. coli TG-1 by electroporation and expression at $24^{\circ} \mathrm{C}$ over 72 hours post IPTG induction ( $1 \mathrm{mmol} / \mathrm{L})$, cells were harvested by centrifugation $\left(7000 \mathrm{~g}, 4^{\circ} \mathrm{C}, 30\right.$ minutes), resuspended in cold MAPS II elution buffer pH 6.8 (BioRad, Germany, 200 $\mathrm{ml} / 100 \mathrm{~g}$ wet cells), and Polymyxin B added $(0.1 \mathrm{mg} / \mathrm{ml})$. After incubation $\left(4^{\circ} \mathrm{C}, 4\right.$ hours, stirring), the cells were spun down and the supernatant collected. The supernatants of three extractions were combined and soluble scFv M6P-1 was purified by affinity chromatography (IMAC, $5 \mathrm{ml}$ HiTrap cartridges, GE Healthcare, Freiburg, Germany) followed by gel filtration on Superdex HR 75 (HiLoad 16/60 Superdex 75 $\mathrm{pg}, \mathrm{GE}$ Healthcare) from the combined supernatants as described ${ }^{21}$ (yield 8 mg scFv M6P-1 per liter culture, determined using a composition derived molar extinction coefficient $\varepsilon=57070$ leading to $\mathrm{A}_{280} 1.0=0.5 \mathrm{mg} / \mathrm{ml}$ ).

\section{ELISA with Phage or Soluble scFv}

ELISA was performed according to the published protocol. ${ }^{19}$ To determine the ligand concentration suitable for phage ELISA the reactivity of $1: 3(\mathrm{v} / \mathrm{v})$ diluted polyclonal phage (titer $\approx 3 \times 10^{12}$ ) after three to five rounds of panning was tested in an ELISA checkerboard titration against different concentrations of PMP-BSA (3-100 pmol/cup; PMP concentration). For ELISA using monoclonal phage or soluble scFv, PMP-BSA was immobilized by addition of $2.25 \mathrm{pmol}$ neoglycoconjugate $(45 \mathrm{pmol}$ PMP ligand, solution in $50 \mathrm{mmol} / \mathrm{L}$ carbonate buffer, $\mathrm{pH}$ 9.2) to each cup of the ELISA plates (MaxiSorp, Nunc) and overnight incubation at $4{ }^{\circ} \mathrm{C}$. Phage were detected using an anti-M13 monoclonal antibody HRP-conjugate (GE Healthcare) and diammonium 2,2'-azino-bis(3-ethylbenzothiazoline-6-sulfonate (AzBTS- $\left(\mathrm{NH}_{4}\right)_{2}$ (Sigma-Aldrich, St. Louis, MO) as substrate. For scFv-ELISA against PMP-BSA purified ScFv was added at a starting concentration of $5 \mu \mathrm{g} / \mathrm{ml}$. Bound ScFv was detected by incubation with anti-c-myc monoclonal antibody (SigmaAldrich) and HRP-conjugated goat-anti-mouse Ig $\mathrm{H}+\mathrm{L}$ (Dianova, Hamburg, Germany). For ELISA inhibition studies, monomeric scFv M6P-1 was freshly prepared by gelfiltration. After preincubation $\left(1\right.$ hour, $\left.37^{\circ} \mathrm{C}\right)$ of $\mathrm{scFv}$ $(0.6 \mu \mathrm{g} / \mathrm{ml}$ final concentration) with increasing concentrations of inhibitor $(0.01-100 \mathrm{mmol} / \mathrm{L}), 50 \mu$ l were added to PMP-BSA (45 pmol/cup ligand concentration) immobilized on ELISA plates and developed as described above. Every data point was measured in quadruplicate. The data were analyzed using Origin v. 6.0 software (MicroCal, Northampton, MA) and fitted to a 4-parameter logistic function. The data obtained for inhibition by Man6 $P$ and Fru1 $P$ were globally fitted to the four replicate data sets each, separately.

\section{Isothermal Titration Microcalorimetry}

The comparison of $I_{50}$ values allows the ranking of different ligands according to their relative affinities, however the absolute affinities in terms of $K_{d}$ cannot be obtained. We have therefore performed isothermal titration microcalorimetry measurements using Man6P as li- gand. Purified dimeric ScFv M6P-1 obtained after gel filtration (see above) was concentrated in Centriprep YM-10 (Millipore, Schwalbach, Germany) to a final concentration of $2.7 \mathrm{mg} / \mathrm{ml}$ in $10 \mathrm{mmol} / \mathrm{L}$ phosphate-buffered saline $\mathrm{pH} 7.4$ (PBS) and dialyzed for 1 hour at $20^{\circ} \mathrm{C}$ against $500 \mathrm{ml}$ of PBS. The same dialysis buffer was used for preparation of a $10 \mathrm{mmol} / \mathrm{L}$ solution of $\operatorname{Man} 6 \mathrm{P}\left(\mathrm{Na}^{+}\right.$salt, Sigma-Aldrich). Microcalorimetric experiments were performed on an MCS isothermal titration calorimeter (Microcal Inc., Northampton, MA). The microcalorimeter cell was filled with the antibody solution (volume $=1.5 \mathrm{ml}$ ) and Man6P in dialysis buffer loaded into the syringe of the microcalorimeter. Both solutions were thoroughly degassed before loading. After temperature equilibration, the ligand was injected into the cell in $4-\mu l$ portions and the evolved heat measured with the first injection $(1 \mu \mathrm{l})$ not considered for data analysis. A total of 21 injections were performed with 8-minute equilibration times between injections. Data were corrected for heat of dilution by measuring the same number of buffer injections and subtraction from the sample data set. Dissociation constants were determined using the MicroCal Origin v. 2.9 analysis software and non-linear least squares curve fitting (one set of binding sites).

\section{scFv M6P-1 Western Blotting}

Fibroblasts were obtained from skin biopsies of control individuals and patients with ML II and ML III for diagnostic purposes. The diagnoses were based on the clinical phenotype, elevated and decreased lysosomal enzyme activities in the serum and in cultured fibroblasts, respectively, and direct sequencing of the GNPTAB and GNPTG genes using genomic DNA of the patients. ${ }^{5,22}$ Cells were maintained in Dulbecco's modified Eagle's medium (DMEM; Gibco Invitrogen, Karlsruhe, Germany) containing 10\% fetal calf serum and penicillin/streptomycin (Gibco Invitrogen). For conditioning, the washed fibroblasts were preincubated in DMEM containing $0.1 \%$ BSA (DMEM/BSA) for 6 hours and further incubated in fresh DMEM/BSA for 24 hours. Extracts of fibroblasts were prepared in PBS containing $0.2 \%$ Triton $\mathrm{X}-100$ and protease inhibitors. Aliquots of cell extracts $(75 \mu \mathrm{g}$ of protein) and ethanol precipitated conditioned media ${ }^{23}$ were solubilized, separated by SDS-PAGE (10\% acrylamide), and blotted onto nitrocellulose (Whatman, Dassel, Germany). After blocking with $10 \mathrm{mmol} / \mathrm{L}$ Tris/ $/ \mathrm{HCl} \mathrm{pH}$ 7.4 containing $1 \%$ BSA and $0.05 \%$ Tween for 4 hours, the membranes were probed with myc-tagged scFv M6P-1 $(5 \mu \mathrm{g} / \mathrm{ml})$ in blocking solution for 6 to 12 hours at $4^{\circ} \mathrm{C}$. After washing, the membranes were incubated with monoclonal anti-myc antibody (9E10, Sigma-Aldrich; 1:1000), followed by washing and incubation with HRPconjugated goat anti-mouse IgG (Dianova; 1:5000). The immunoreactive bands were visualized by enhanced chemiluminescence (Pierce). AIDA software (Raytest, Straubenhardt, Germany) was used for evaluation of immunoreactive band intensities. 


\section{Immobilization of scFv M6P-1 on Beads}

Monomeric or dimeric scFv M6P-1 $(\sim 1 \mathrm{mg} / \mathrm{ml}$ in PBS, $\mathrm{pH}$ 7.2 ) isolated by gel filtration (see above) was chemically immobilized to AminoLink Plus Coupling Gel beads (Pierce) following the suppliers instructions (1 mg scFv M6P-1 to $2 \mathrm{ml}$ of settled beads).

\section{Immunohistochemistry}

Paraffin sections $(3 \mu \mathrm{m})$ were immunostained with myctagged scFv M6P-1 (2 $\mu \mathrm{g} / \mathrm{ml})$. After blocking of endogenous peroxidase activity the samples were incubated with HRP-coupled anti-myc antibody (9E10; 1:200, BIOMOL Research Laboratories, Plymouth, PA) and visualized by means of the Histofine stain kit (Nichirei, Tokyo, Japan).

\section{Patients}

Paraffin-embedded brain tissue from a 2-year-old male ML II patient and one patient with no disease affecting the central nervous system (48-year-old male) were examined in agreement with local ethical standards at the University of Hamburg.

\section{Immunoprecipitation of [25/]ASA and Man6P-Containing Proteins}

[125I]ASA $(400,000 \mathrm{cpm})$ was incubated with $50 \mu \mathrm{l} \mathrm{scFv}$ M6P-1-conjugated beads in PBS containing $0.05 \%$ Triton $\mathrm{X}-100$ in a final volume of $0.5 \mathrm{ml}$ in the absence or presence of effectors for 10 hours at $4^{\circ} \mathrm{C}$. Bound $\left[{ }^{125}\right.$ I]ASA was solubilized, separated by SDS-PAGE (10\% acrylamide), visualized by autoradiography, and quantified by densitometry or excision and counting of [ $\left.{ }^{125} \mathrm{l}\right]$ labeled polypeptides from the dried gel.

Man6P-containing proteins were precipitated from media conditioned for 24 hours by baby hamster kidney (BHK) cells overexpressing either human ASA or mouse cathepsin D. ${ }^{24,25}$ The immunocomplexes were solubilized, separated by SDS-PAGE, and subsequently analyzed by anti-hASA and mouse cathepsin D (mCtsD) Western blotting. Aliquots of mouse brain extracts (300 $\mu \mathrm{g}$ protein) in PBS containing 1\% Triton X-100 and protease inhibitors were incubated with $50 \mu \mathrm{l} \mathrm{scFv} \mathrm{M6P-1-}$ conjugated beads in a final volume of $0.5 \mathrm{ml}$ for 10 hours at $4^{\circ} \mathrm{C}$. The precipitated immunocomplexes were washed, solubilized, and analyzed by myc-tagged scFv M6P-1 or $\mathrm{mCtsD}$ Western blotting. When indicated, cell extracts were deglycosylated by incubation with $1 \mathrm{U}$ peptide $\mathrm{N}$-glycosidase F (PNGase F; Boehringer, Mannheim, Germany) for 16 hours at $37^{\circ} \mathrm{C}$.

\section{Generation of Gnptab Knock-In Mice}

Targeting vector construction and knock-in strategy has been designed and performed by geneOway (Lyon, France). Ten kb of mouse genomic DNA encompassing the murine Gnptab gene region surrounding exons 11 to
19 have been isolated from a genomic DNA library (129/ SvPas) and sequenced. The construction of the final targeting vector comprising genomic sequences of the exon 12 to 18 with the inserted mutation c.3082insC in exon 16 and the generation of the Gnptab knock-in mice will be described elsewhere (K. Kollmann and T. Braulke, manuscript in preparation).

\section{Results}

\section{Characterization of the Single-Chain Antibody Fragment against Man6P}

Immunization of a rabbit with PMP-BSA and panning of recombinant scFv antibodies displayed on phage allowed the isolation of the PMP-binding ScFv M6P-1. Binding of ScFv M6P-1 to the antigen in ELISA could be inhibited by Man6P $\left(\mathrm{IC}_{50} 2.3 \mathrm{mmol} / \mathrm{L}\right)$ and the structurally similar fructose 1-phosphate (Fru1P; $\left.I \mathrm{C}_{50} 1.1 \mathrm{mmol} / \mathrm{L}\right)$ but not by mannose (Man), glucose (Glc), or glucose 6-phosphate (Glc6P; Figure 1A). Conjugation of scFv M6P-1 to beads allowed the immunoprecipitation of the purified human [ $\left.{ }^{125} \mathrm{I}\right]$-labeled lysosomal enzyme arylsulfatase $A$ (ASA). Equal aliquots of $\left[{ }^{125} \mathrm{I}\right] \mathrm{ASA}$ were incubated with ScFv M6P-1 conjugated beads and increasing concentrations of Man6P at $4^{\circ} \mathrm{C}$. The $\left[{ }^{125} \mathrm{I}\right] \mathrm{ASA}$-antibody fragment complexes were precipitated, separated by SDSPAGE, and visualized by autoradiography. About 20\% to $25 \%$ of total offered [ ${ }^{125} \mathrm{I}$ ]ASA bound in a Man6P-dependent manner to the antibody beads (Figure 1B). Man6P inhibited the binding of $\left[{ }^{125} \mathrm{I}\right] \mathrm{ASA}$ to the antibody fragment-conjugated beads in a concentration-dependent manner indicating the specificity of scFv M6P-1. The evaluation of the autoradiographs by densitometry or excision of the $\left[{ }^{125} \mathrm{l}\right]$-labeled bands and direct counting the radioactivity revealed a $K_{i}$ value of Man6P of 100 $\mu \mathrm{mol} / \mathrm{L}$. Isothermal titration microcalorimetry measurements yielded a $K_{d}$ of $28 \mu \mathrm{mol} / \mathrm{L}$ (Figure $1 \mathrm{C}$ ).

To determine the specificity of scFv M6P-1 for Man6Pcontaining lysosomal enzymes, antibody fragment-coupled beads were used for immunoprecipitation of human ASA or murine CtsD from media of overexpressing cells alone or in combination, which was documented by subsequent Western blotting (Figure 2A). Both enzymes were detectable in the media of respective overexpressing cells and could be precipitated simultaneously from mixed media. The precipitation of the lysosomal enzymes was inhibited by Man6P. In media of nontransfected cells no hASA or mCtsD immunoreactive bands were observed. In another approach Man6P-containing proteins were precipitated by scFv M6P-1-coupled beads from mouse brain extracts in the presence or absence of Man6P. Analysis of the immunocomplexes by Western blotting comparing Man6 $P$ with cathepsin D immunoreactivity showed that the abundant $47 \mathrm{kDa}$ Man6P-containing polypeptide in the precipitates represent cathep$\sin \mathrm{D}$ (Figure 2B). 
A

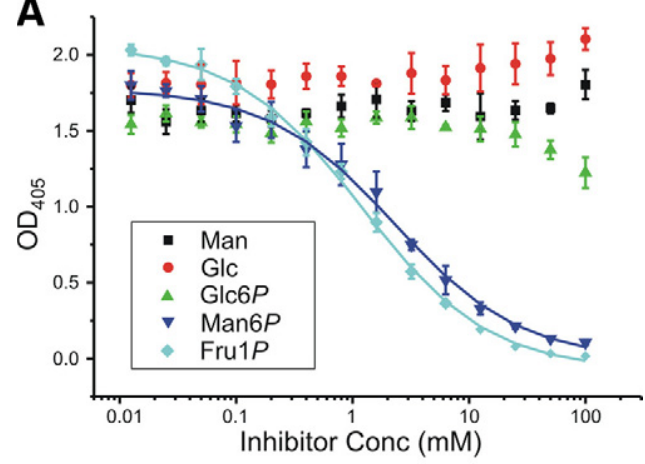

B

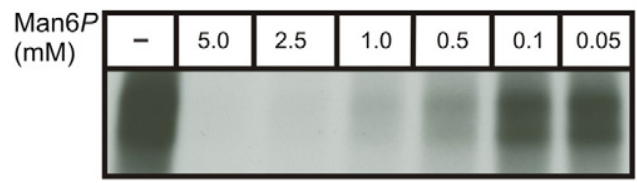

C

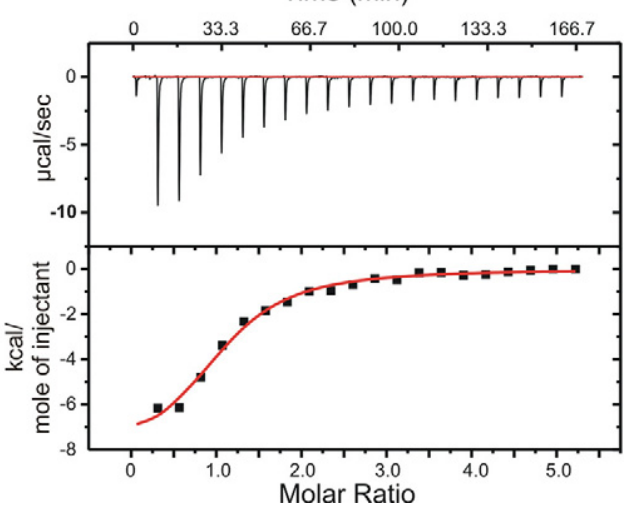

Figure 1. Specificity of scFv M6P-1. A: Binding of scFv M6P-1 (30 ng) preincubated with or without 0.01 to $100 \mathrm{mmol} / \mathrm{L}$ of Man, Glc, Glc6P, Fru1P, or Man6P to immobilized PMP-BSA ( 45 pmoles). Bound scFv M6P-1 was quantified spectrophotometrically. Data were measured in quadruplicate and expressed as mean \pm SD. B: Man6P-dependent precipitation of $\left[{ }^{125} \mathrm{I}\right]$-labeled ASA after incubation with ScFv M6P-1-coupled beads. Bound material was eluted, separated by SDS-PAGE, and visualized by autoradiography. The experiment was repeated three times with similar results. C: ITC microcalorimetry using a $0.12 \mathrm{mmol} / \mathrm{L}$ solution of $\mathrm{scFv} \mathrm{M} 6 \mathrm{P}-1$ in PBS. Shown are the results of 20 injections ( $4 \mu \mathrm{l} \mathrm{each}$ ) of $10 \mathrm{mmol} / \mathrm{L}$ Man6P.

\section{Application of SCFv M6P-1 in Diagnosis of ML II and $M L I I I$}

The high specificity of scFv M6P-1 for Man6P and its ability to recognize these residues on lysosomal enzymes allows its use in the diagnosis of mucolipidoses. When extracts of cultured fibroblasts and aliquots of media of healthy control individuals and patients with confirmed ML II and ML III were analyzed by Western blotting using myc-tagged ScFv M6P-1, seven major immunoreactive bands of 95, 83, 74, 64, 52, 40, and 34 $\mathrm{kDa}$ were stained in control cells (Figure $3, \mathrm{~A}$ and $\mathrm{B}$ ) representing Man6P-containing proteins. Double immunofluorescence microscopy revealed the colocalization of Man6P-containing proteins with lysosomal marker proteins cathepsin D (see supplemental Figure 1 at $h$ ttp://ajp.amjpathol.org) or LAMP-1 (not shown). In media, three prominent immunoreactive bands were
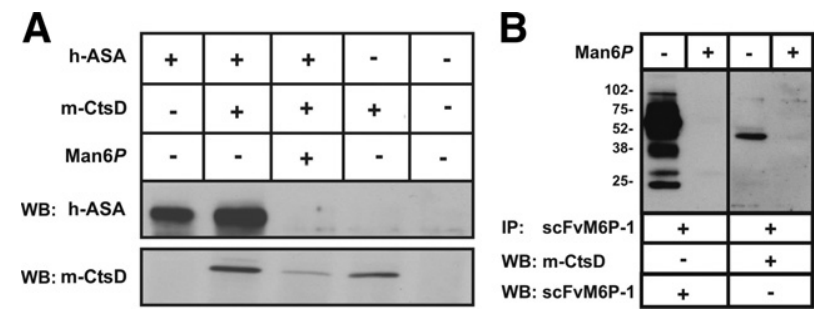

Figure 2. Precipitation of Man6P-containing lysosomal enzymes. A: Purification of Man6P-containing lysosomal enzymes from media of overexpressing cells. Serum-free media from BHK cells stably overexpressing human ASA or transiently expressing mouse cathepsin D (mCtsD) were conditioned for 24 hours. Aliquots of the media $(0.25 \mathrm{ml})$ were either mixed with $0.25 \mathrm{~m}$ of the other overexpressing cell line or of nontransfected cells and incubated with $50 \mu \mathrm{l}$ of scFv M6P-1-coupled beads in the presence or absence of M6P $(5 \mathrm{mmol} / \mathrm{L})$ for ten hours at $4^{\circ} \mathrm{C}$. Then the samples were centrifuged and the supernatant removed. The proteins bound to the ScFv M6P-1-coupled beads were solubilized and analyzed by Western blotting using anti-ASA and anti-mCtsD polyclonal antibodies. B: Equal aliquots of brain extracts $(300 \mu \mathrm{g}$ protein) of 8 -week-old mice were incubated with $50 \mu \mathrm{l}$ of scFv M6P-1-coupled beads in the presence $(+)$ or absence $(-)$ of M6P (5 $\mathrm{mmol} / \mathrm{L}$ ) for 10 hours at $4^{\circ} \mathrm{C}$ (IP). The immunocomplexes were precipi tated, washed, solubilized, and analyzed by scFv M6P-1 or mCtsD Western blotting (WB). The positions of the molecular mass marker proteins (in $\mathrm{kDa}$ ) are indicated.

present, which represented higher molecular mass precursor proteins that failed to bind to Man6P receptors in the Golgi apparatus. Importantly, media of cultured fibroblasts of ML II or ML III patients (Figure 3) did not contain immunoreactive material at all. In cell extracts, only weakly stained bands were observed, which differed in size from immunoreactive bands in control cells. Thus, Western blot analysis using scFv M6P-1 provides an additional tool for the diagnosis of ML II/ML III diseases.

ScFv M6P-1 can be used also in immunohistochemical stainings on human brain sections. A very strong scFv M6P-1 immunoreactivity was observed in cerebellar Purkinje cells, cortical neurons, and hippocampal pyramidal cells rather than glial cells in human (Figure 4, A and B) and mouse brain tissue (see supplemental Figure 2 at http://ajp.amjpathol.org), whereas no labeling has been found in parallel stainings of cortical sections of an ML II patient (Figure 4, C and D).
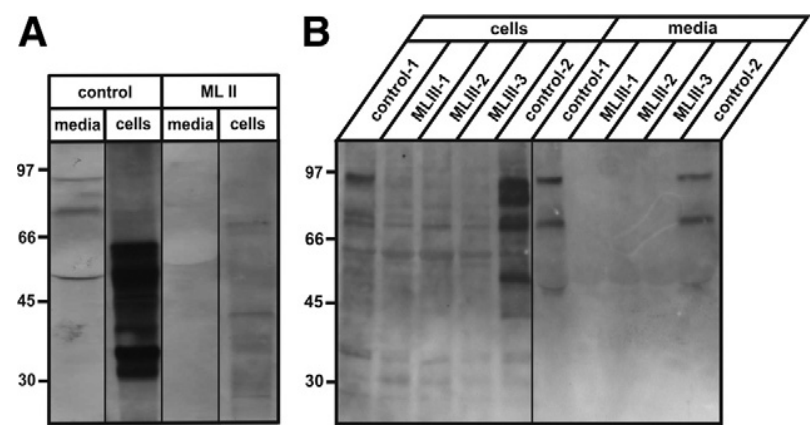

Figure 3. Diagnosis of mucolipidosis II and III in cultured fibroblasts Extracts of cultured fibroblasts ( $75 \mu \mathrm{g}$ protein) and aliquots of media conditioned for 24 hours of healthy control individuals and an ML II (A) or three ML III patients (B) were separated by SDS-PAGE ( $10 \%$ acrylamide), and Man6P-containing proteins were detected by scFv M6P-1 Western blotting. The positions of the molecular mass marker proteins (in $\mathrm{kDa})$ are indicated. 

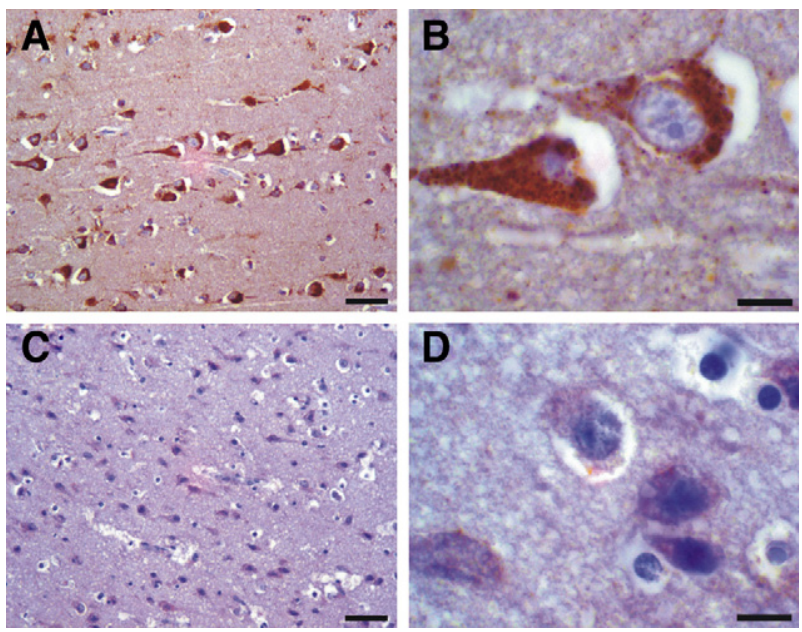

Figure 4. Immunostaining for Man $6 P$-containing proteins in human brain sections. Paraffin-fixed cortical sections of an adult male unaffected patient (A and $\mathbf{B}$ ) and a male child suffering from mucolipidosis II (C and $\mathbf{D}$ ) were incubated with myc-tagged scFv M6P-1 followed by the peroxidase-diaminobenzidine reaction. In control brain samples strong staining was observed in soma and extensions of neurons of the cerebral cortex and the brain stem (A, Scale bar $=80 \mu \mathrm{m})$, which are not detectable in brain sections of the ML II patient $(\mathbf{C}$, scale bar $=80 \mu \mathrm{m} ; \mathbf{D}$, scale bar $=20 \mu \mathrm{m})$. Higher magnifications of the immunostained control sections showed the presence of Man6P-containing vesicular structures in the cytoplasm of neurons (B, Scale bar $=20 \mu \mathrm{m})$.

\section{Absence of Man6P-Containing Proteins in Brain Extracts of ML II Knock-In Mice}

A novel ML II mouse model was generated by insertion of a single cytosine in the Gnptab gene (c.3082insC), which encodes the murine GlcNAc-1-phosphotransferase. The cytosine insertion corresponds to the human c.3145insC mutation detected in an ML $\|$ patient. $^{5}$ No GlcNAc-1phosphotransferase activity was detectable in fibroblasts of this patient (B. J. Poorthuis, Amsterdam; personal communication). Biochemically c.3082insC Gnptab knock-in mice should confirm the ML II phenotype and fail to generate Man6P recognition marker on lysosomal enzymes. When extracts of brain tissue of 4-week-old wildtype and c.3082insC Gnptab knock-in mice were analyzed by scFv M6P-1 Western blotting, comparable amounts and pattern of immunoreactive polypeptides between 30 and $100 \mathrm{kDa}$ were observed both in wild-type and heterozygous knock-in mice (Figure 5A). No Man6Pcontaining proteins were detectable in extracts of the ML II knock-in mice. To exclude unspecific binding of the scFv M6P-1 antibody fragment, Man6P-containing proteins were immunoprecipitated from mouse brain and incubated in the absence and the presence of peptide $\mathrm{N}$-glycosidase $\mathrm{F}$ (PNGase F), which removes all $N$-linked oligosaccharides including Man6P-containing high mannose-type sugar chains. ScFv M6P-1 Western blot analysis demonstrated that the immunoreactivity of deglycosylated samples was lost completely (Figure 5B). Furthermore, the addition of $5 \mathrm{mmol} / \mathrm{L}$ Man6P to the blotting solution inhibited the binding of ScFv M6P-1 to transferred polypeptides (Figure 5B). These data indicate that ScFv M6P-1 binds specifically to oligosaccharides on murine glycoproteins equipped with Man6P residues.
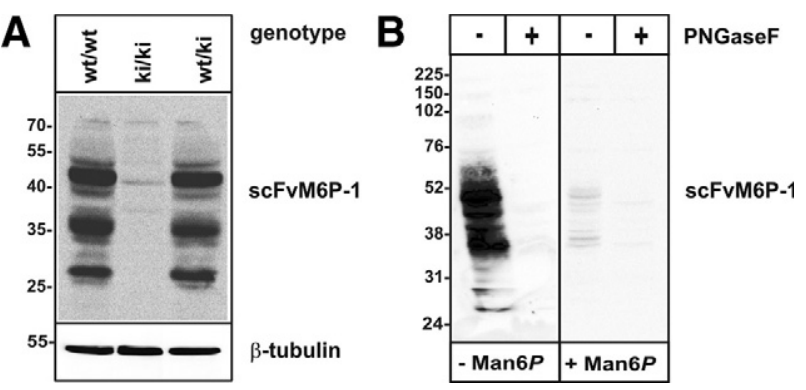

Figure 5. Absence of Man6P-containing proteins in brain tissue of ML II knock-in mice. A: Man6P-containing proteins were examined in extracts of total brain tissue ( $200 \mu \mathrm{g}$ protein) of wild-type (wt/wt), heterozygous (wt/ki), and Gnptab c.3082insC knock-in (ki/ki) mice by scFv M6P-1 Western blotting. The positions of the molecular mass marker proteins (in $\mathrm{kDa}$ ) are indicated. Equal loading of the gel was confirmed by $\beta$-tubulin immunoblotting. B: Extracts of total brain tissue of wild-type mice were deglycosylated $(+)$ or not by incubation with PNGase F (1U for 16 hours). The samples were solubilized, divided into equal aliquots, separated by SDS-PAGE (10\% acrylamide), blotted onto nitrocellulose membranes, incubated with scFv M6P-1 in the absence $(-\operatorname{Man} 6 P)$ or presence of $5 \mathrm{mmol} / \mathrm{L}$ Man $6 P(+\operatorname{Man} 6 P)$, and visualized by electrochemiluminescence. The positions of the molecular mass marker proteins (in $\mathrm{kDa}$ ) are indicated.

\section{Discussion}

The principal aim of this study was to develop and validate a method for direct demonstration of Man6P residues on glycoproteins and the indirect determination of GlcNAc-1-phosphotransferase activity. At present, iodinated or biotinylated soluble MPR300 purified from bovine serum has been used in a few laboratories to detect and affinity purify Man6P-containing proteins from various human and mouse tissues and body fluids. ${ }^{26-28}$ The binding specificities, however, of the MPR300 for non-Man6Pcontaining ligands, such as IGF II or urokinase-type plasminogen activator receptor and its capability to bind also Man6P-GlcNAc phosphodiester ${ }^{29-31}$ represents a major drawback of the MPR approach. Moreover, MPR300 exhibits preferential binding properties for distinct lysosomal enzymes compared with the MPR46. ${ }^{28}$ Thus, the generation of recombinant small single-chain antibody fragments against Man6P presented here is a considerable improvement over the soluble MPR300, allowing the specific and nonradioactive detection and the cellular and histochemical localization of Man6P-containing proteins. Moreover, the high affinity of the scFv M6P-1 for Man6P similar to $K_{d}$ values determined for MPR ${ }^{32}$ warrants its usage as rapid supplementary diagnostic tool to diagnose ML II and ML III by Western blotting, which is less expensive than sequencing of GNPTAB and GNPTG genes. In families at risk exhibiting intronic mutations of unknown pathogenity, Man6P Western blots might be helpful also for prenatal diagnosis.

In addition to human cells and tissues, we have investigated the expression of Man6P-containing proteins in mouse brain tissue of wild-type mice in comparison with a novel Gnptab knock-in mouse (c.3082insC). The insertion of the single cytosine in Gnptab predicts to cause a premature termination of translation in the C-terminal conserved region (p.G1028RfsX16), which results in the loss of GlcNAc-1-phosphotransferase activity. The scFv M6P-1 Western blot confirmed the absence of Man6P residues on lysosomal enzymes in the brain of 
Gnptab knock-in mouse. The amounts of Man6P-containing proteins in brain extracts of both wild-type and heterozygous knock-in mice were comparable. Thus, the lack of Man6P residues in Gnptab knock-in mouse resembles the human condition and makes it a proper model to study molecular pathomechanisms of ML II. Furthermore, the data provide evidence that the ScFv M6P-1 antibody fragment is applicable in lysosome research in a speciesindependent manner.

ML II and ML III belong to a group of more than 50 lysosomal storage disorders resulting from the deficiency of soluble lysosomal enzymes, lysosomal membrane proteins, activator proteins, or nonlysosomal proteins involved in posttranslational processing or transport of lysosomal proteins. ${ }^{33}$ For some of those diseases, which are caused by defective single lysosomal enzymes, such as M. Fabry, M. Pompe, and mucopolysaccharidosis type I, II, and VI, enzyme replacement therapies are available. ${ }^{34}$ The rationale of this treatment is the Man6Pdependent cellular uptake of the missing enzymes through MPR300 at the cell surface and their subsequent transport to lysosomes where the disease-dependent storage material can be degraded. The required enzymes are purified from media of stably expressing Chinese Hamster Ovary-S cells by several chromatographic procedures. Here we show that ScFv M6P-1-conjugated beads can be used to enrich and purify lysosomal hASA or mouse cathepsin $\mathrm{D}$ from conditioned media of overexpressing BHK cells in a Man6P-dependent manner (Figure 2A). This one-step purification procedure suggests a possibility to separate Man6P-containing high affinity uptake forms from nonphosphorylated recombinant enzymes, which might have an impact on enzyme replacement therapies.

In summary, the recombinant scFv M6P-1 antibody will be of considerable value in basic research studies requiring purified lysosomal hydrolases, investigating structural requirements of the GlcNAc-1-phosphotransferase for enzymatic activity, or to examine the role of Man6P-residues in transport, sorting, and localization of lysosomal enzymes. More samples of patients, however, have to be tested to validate its potential application in laboratory diagnosis of ML II and ML III.

\section{Acknowledgments}

We thank Nadine Harmel and Inke Stange for technical assistance.

\section{References}

1. Pohl S, Marschner K, Storch S, Braulke T: Glycosylation- and phosphorylation-dependent intracellular transport of Iysosomal hydrolases. Biol Chem 2009, 390:521-527

2. Kornfeld S, Sly WS: I-cell disease and pseudo-Hurler polydystrophy: disorders of lysosomal enzyme phosphorylation and localization. The Metabolic and Molecular Bases of Inherited Disease. Edited by Scriver CR, Beaudet AL, Sly WS, Valle D, Childs B, Kinzler KW, Vogelstein B. New York, McGraw-Hill Inc., 2001, pp 3421-3452

3. Braulke T, Bonifacino JS: Sorting of lysosomal proteins. Biochim Biophys Acta 2009, 1793:605-614
4. Kudo M, Bao M, D'Souza A, Ying F, Pan H, Roe BA, Canfield WM: The alpha- and beta-subunits of the human UDP-N-acetylglucosamine: lysosomal enzyme $\mathrm{N}$-acetylglucosamine-1-phosphotransferase [corrected] are encoded by a single cDNA. J Biol Chem 2005, 280:3614136149

5. Tiede S, Storch S, Lübke T, Henrissat B, Bargal R, Raas-Rothschild A, Braulke T: Mucolipidosis II is caused by mutations in GNPTA encoding the alpha/beta GlcNAc-1-phosphotransferase. Nat Med 2005, 11:1109-1112

6. Raas-Rothschild A, Cormier-Daire V, Bao M, Genin E, Salomon R, Brewer K, Zeigler M, Mandel H, Toth S, Roe B, Munnich A, Canfield WM: Molecular basis of variant pseudo-hurler polydystrophy (mucolipidosis IIIC). J Clin Invest 2000, 105:673-681

7. Hasilik A, Waheed A, von Figura K: Enzymatic phosphorylation of lysosomal enzymes in the presence of UDP-N-acetylglucosamine. Absence of the activity in I-cell fibroblasts. Biochem Biophys Res Commun 1981, 98:761-767

8. Reitman ML, Varki A, Kornfeld S: Fibroblasts from patients with I-cell disease and pseudo-Hurler polydystrophy are deficient in uridine 5'diphosphate-N-acetylglucosamine: glycoprotein N-acetylglucosaminylphosphotransferase activity. J Clin Invest 1981, 67:1574-1579

9. Kudo M, Brem MS, Canfield WM: Mucolipidosis II (I-cell disease) and mucolipidosis IIIA (classical pseudo-hurler polydystrophy) are caused by mutations in the GlcNAc-phosphotransferase alpha/beta -subunits precursor gene. Am J Hum Genet 2006, 78:451-463

10. Kelly TE, Thomas GH, Taylor HA, McKusick VA: Mucolipidosis III: clinical and laboratory findings. Birth Defects Orig Artic Ser 1975, 11:295-299

11. Spranger JW, Wiedemann HR: The genetic mucolipidoses. Diagnosis and differential diagnosis. Humangenetik 1970, 9:113-139

12. Hieber V, Distler J, Jourdian GW, Schmickel R: Accumulation of 32S-mucopolysaccharides in cultured mucolipidosis cells. Birth Defects Orig Artic Ser 1975, 11:307-310

13. Bargal R, Zeigler M, Abu-Libdeh B, Zuri V, Mandel H, Ben Neriah Z, Stewart F, Elcioglu N, Hindi T, Le Merrer M, Bach G, Raas-Rothschild A: When Mucolipidosis III meets Mucolipidosis II: gNPTA gene mutations in 24 patients. Mol Genet Metab 2006, 88:359-363

14. Otomo T, Muramatsu T, Yorifuji T, Okuyama T, Nakabayashi H, Fukao T, Ohura T, Yoshino M, Tanaka A, Okamoto N, Inui K, Ozono K, Sakai $\mathrm{N}$ : Mucolipidosis II and III alpha/beta: mutation analysis of 40 Japanese patients showed genotype-phenotype correlation. J Hum Genet 2009, 54:145-151

15. Paik KH, Song SM, Ki CS, Yu HW, Kim JS, Min KH, Chang SH, Yoo EJ, Lee IJ, Kwan EK, Han SJ, Jin DK: Identification of mutations in the GNPTA (MGC4170) gene coding for GlcNAc-phosphotransferase alpha/beta subunits in Korean patients with mucolipidosis type II or type IIIA. Hum Mutat 2005, 26:308-314

16. Raas-Rothschild A, Bargal R, Goldman O, Ben-Asher E, Groener JE, Toutain A, Stemmer E, Ben-Neriah Z, Flusser H, Beemer FA, Penttinen M, Olender T, Rein AJ, Bach G, Zeigler M: Genomic organisation of the UDP-N-acetylglucosamine-1-phosphotransferase gamma subunit (GNPTAG) and its mutations in mucolipidosis III. J Med Genet 2004, 41:e52

17. Braulke T, Gartung C, Hasilik A, von Figura K: Is movement of mannose 6-phosphate-specific receptor triggered by binding of lysosomal enzymes? J Cell Biol 1987, 104:1735-1742

18. Dierks T, Schmidt B, von Figura K: Conversion of cysteine to formylglycine: a protein modification in the endoplasmic reticulum. Proc Natl Acad Sci U S A 1997, 94:11963-11968

19. Andris-Widhopf J, Steinberger P, Fuller R, Rader C, Barbas III CF: Generation of antibody libraries: PCR amplification and assembly of light- and heavy-chain coding sequences. Phage-Display: A Laboratory Manual. Edited by Barbas CF III, Burton DR, Scott JK, Silverman GJ. Cold Spring Harbor, NY, Cold Spring Harbor Laboratory Press, 2001, pp 9.79-79.89

20. MacKenzie CR, Hirama T: Quantitative analyses of binding affinity and specificity for glycolipid receptors by surface plasmon resonance. Methods Enzymol 2000, 312:205-216

21. Anand NN, Mandal S, MacKenzie CR, Sadowska J, Sigurskjold B Young NM, Bundle DR, Narang SA: Bacterial expression and secretion of various single-chain Fv genes encoding proteins specific for a Salmonella serotype B O-antigen. J Biol Chem 1991, 266:21874-21879

22. Tiede S, Cantz M, Raas-Rothschild A, Muschol N, Bürger F, Ullrich K, Braulke T: A novel mutation in UDP-N-acetylglucosamine-1-phospho- 
transferase gamma subunit (GNPTAG) in two siblings with mucolipidosis type III alters a used glycosylation site. Hum Mutat 2004, 24:535

23. Shalamanova L, Kübler B, Scharf JG, Braulke T: MDCK cells secrete neutral proteases cleaving insulin-like growth factor-binding protein-2 to -6. Am J Physiol Endocrinol Metab 2001, 281:E1221-E1229

24. Braulke T, Tippmer S, Chao H-J, von Figura K: Insulin-like growth factors I and || stimulate endocytosis but do not affect sorting of lysosomal enzymes in human fibroblasts. J Biol Chem 1990, 265:6650-6655

25. Partanen S, Storch S, Löffler HG, Hasilik A, Tynnelä J, Braulke T: A replacement of the active-site aspartic acid residue 293 in mouse cathepsin $\mathrm{D}$ affects its intracellular stability, processing and transport in HEK-293 cells. Biochem J 2003, 369:55-62

26. Journet A, Chapel A, Kieffer S, Roux F, Garin J: Proteomic analysis of human lysosomes: application to monocytic and breast cancer cells. Proteomics 2002, 2:1026-1040

27. Lübke T, Lobel P, Sleat DE: Proteomics of the lysosome. Biochim Biophys Acta 2009, 1793:625-635

28. Qian M, Sleat DE, Zheng H, Moore D, Lobel P: Proteomics analysis of serum from mutant mice reveals lysosomal proteins selectively trans- ported by each of the two mannose 6-phosphate receptors. Mol Cell Proteomics 2008, 7:58-70

29. Dahms NM, Olson LJ, Kim JJ: Strategies for carbohydrate recognition by the mannose 6-phosphate receptors. Glycobiology 2008, 18:664-678

30. Valenzano KJ, Heath-Monnig E, Tollefsen SE, Lake M, Lobel P: Biophysical and biological properties of naturally occurring high molecular weight insulin-like growth factor II variants. J Biol Chem 1997, 272:4804-4813

31. Olson LJ, Yammani RD, Dahms NM, Kim JJ: Structure of UPAR, plasminogen, and sugar-binding sites of the $300 \mathrm{kDa}$ mannose 6-phosphate receptor. EMBO J 2004, 23:2019-2028

32. Tong PY, Kornfeld S: Ligand interactions of the cation-dependent mannose 6-phosphate receptor. Comparison with the cation-independent mannose 6-phosphate receptor J Biol Chem 1989, 264:7970-7975

33. Ballabio A, Gieselmann V: Lysosomal disorders: from storage to cellular damage. Biochim Biophys Acta 2009, 1793:684-696

34. Keutzer J, Yee J: Enzyme replacement therapy for lysosomal storage disorders. Hum Gene Ther 2008, 19:857 